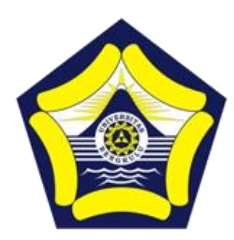

\title{
The Effects of Climate and Work Motivation on Junior High School Teachers' Work Performance in the Losari Sub-District of Brebes Regency
}

\author{
Ipong Dekawati *, Nani Hermawati, Aan Juhana Senjaya \\ Universitas Wiralodra, Jawa Barat \\ *Email: ipongdekawati@unwir.ac.id
}

DOI: https://doi.org/10.33369/jeml.2.1.16-28

\begin{abstract}
Teacher performance is a critical factor in obtaining the desired level of educational quality, meaning meeting national requirements. Various factors, such as the climate and job motivation, have an impact on teacher performance. As a result, the primary goal of this research is to identify and investigate the effects of climate and job motivation on teacher performance. The descriptive method with a quantitative approach was employed in this study. The research sample was determined proportionately random sampling of 155 respondents from a population of 262. Questionnaires, interview techniques, observation, and documentation are all used to collect data. The regression and correlation analysis approaches were used in the data analysis. The findings of this study show that: (1) Workplace atmosphere has a favorable and significant impact on teacher performance; (2) Work motivation has a favorable impact on teacher performance; (3) Both the work climate and job motivation have a good and considerable impact on teacher performance. Based on these circumstances, the authors propose that: (1) Work atmosphere and motivation have an impact on teacher performance, according to research findings. Meanwhile, teacher performance, particularly in terms of planning and implementing learning, remains a source of worry. As a result, the principle should assist teachers on how to create a proper learning implementation plan and conduct supervision so that learning is better implemented; (2) To improve teacher performance through improving the work environment, clear regulations and more support for a smooth learning process should be prioritized. Meanwhile, to improve teacher performance through work motivation, an emphasis on negative motivation should be implemented, with appropriate rewards and punishments.
\end{abstract}

Keywords: Work Climate, Work Motivation, Teacher Performance.

\section{INTRODUCTION}

Education must be able to produce quality Indonesian human resources as part of the country's growth toward a new Indonesia (HR). Quality human resources can be realized if education leaders can maintain control and organization so that all members of the organization are motivated and engaged in achieving their objectives. In today's increasingly competitive global environment, the demand for qualified and competent human resources is critical. As a result, businesses and educational institutions alike design programs to enhance their people resources. One of the functions of human resource management is to support employees in carrying out their jobs in order to produce better results, be more responsible, and always strive to establish a work environment that allows them to maximize their potential (Dekawati, 2020).

Following Law No. 20 of 2003 concerning the National Education System, which states that the position of teacher as an educator is a professional position, professional educators are critical to achieving the goals of national education, namely to educate the nation's life and develop the whole human being. Teacher professionalism must continue to improve in light of contemporary advancements, science, and technology in order to compete in national and international forums.

According to the advancement of science and technology, including a new paradigm of education, a teacher must constantly improve his professional talents, knowledge, attitudes, and skills. (1) Learning Management Competence and Educational Insights, (2) Academic / Vocational Competence according to learning materials, and (3) Professional Development are the three competency standards that a teacher must 
achieve. These three skills are aimed at producing excellent instructors and learning, which will improve the quality of Indonesian education in the long run (Syarifudin, 2019).

Teacher performance in educational institutions is a critical issue that necessitates each institution making arrangements and changes based on space and time constraints. Particularly for educational institutions charged with carrying out their primary activities and functions in a systematic and timely manner. This need is a global trend that, like it or not, will inevitably be addressed in order to synchronize teacher performance within educational institutions, which accelerates external change through a variety of methods.

Efforts to improve teacher performance in educational institutions are continuing, with a focus on improving teacher quality, increasing human resources' ability to solve various problems, and increasing educational institutions' responsibility for problems and demands from both within and outside the institution. Teachers must develop and utilise their professional abilities in order to improve their performance in carrying out their tasks and functions, as future education will necessitate high-quality professional skills.

There are issues with teacher performance that are not yet optimal, based on observations and preliminary conversations with administrators and state junior high school instructors. Some teachers' lesson plans and syllabi are nevertheless inappropriate for the contexts and circumstances of the pupils being taught. In addition, some teachers continue to use less diverse media and learning approaches in their classrooms. The teacher does not adequately assess the learning that takes place in the classroom. Teachers must ask the proper questions because they need the right data or information about students' learning outcomes and level of mastery of the content, but they do not reflect on their own teaching methods and tactics in class.

Improving teacher performance is not solely dependent on the teacher in the classroom; numerous factors influence teacher performance. According to Mulyasa (2007), at least ten elements, both internal and external, can increase teacher performance: The ten factors are: (1) motivation to work, (2) responsibility for duties, (3) interest in assignments, (4) respect for assignments, (5) opportunities for development, (6) attention from school principals, (7) interpersonal relationships with fellow teachers, (8) MGMP and KKG, (2009) guided discussion groups, and 10) library services Surya (2004), on the other hand, expressed a different viewpoint on the factors that determine teacher performance. Job satisfaction, which is closely tied to teacher welfare, is a core element that is closely related to teacher professional performance. (1) remuneration, (2) security, (3) interpersonal interactions, (4) working circumstances, and (5) possibilities for self-development and improvement are all variables that contribute to job satisfaction. As a result, one way to improve teacher performance is to create a positive work environment in the classroom, both physically and mentally, as well as to increase teacher motivation or incentive to work professionally.

The work climate is a type of favorable work environment that describes the atmosphere and working relationships between instructors, between teachers and school principals, between teachers and other education workers, and between offices in their setting. Teachers and principals require this type of environment in order to do their jobs more efficiently. A conducive school climate can affect teacher performance in a school, which can be in the form of a physical and non-physical work climate, according to Arikunto et al (2015).

"The climate and culture of school organizations are fun and constantly sustains a teacher so that they work energetically to improve their work, which is derived from a synergistic collaborative collaboration between schools, government, and educational communities," according to Batlolona (2018). The Principal is responsible for efficiently and successfully managing all school resources in order to improve the school and provide a work environment that encourages teachers to continue to initiate, artistically, and innovatively produce learning materials presented in the classroom. The results of the work climate research at Madrasah Aliyah in Gantarang District, Bulukumba Regency, according to Hamsah, et al (2019), have a beneficial effect on teacher performance. The work climate, according to De Roche (Malang, 2012), can be split into two categories: negative work climate and good work climate. In schools, there is a bad work climate characterized by a lack of direction, communication, creativity and innovation, student exclusion, and so on. Whereas in a positive work climate, school members are aware of the causes of a conflict and take steps to resolve it, conflict and criticism are seen as opportunities to recognize strengths and weaknesses, the principal values each student's ideas, suggestions, and participation, trust and openness, productivity, cooperation, and involvement of high school citizens, and so on.

Encouragement is the definition of motivation. Encouragement is a mental activity and a teacher's behavior that motivates students to act. While the motive can be described as a driving force, it refers to 
something that can motivate a teacher to take action or conduct, with a specific goal in mind. Usman (2013) defines motivation as a person's desire to accomplish something, whereas the motive can be a need (need), desire (desire), urge (desire), or impulse. Motivation is the drive that a teacher has to motivate students to take action or to do something that forms the foundation or reason for someone to act or behave in a certain way. Work motivation can be defined as an encouragement to a teacher to engage in a job-related activity. Ardiana's research (2017) reveals that work motivation has a favorable impact on accounting teachers' performance at Madiun City Vocational High School. Work motivation, according to Rahmi and Zulminiati (2019), has a good association with Kindergarten teacher performance. Kindergarten teachers will do well if they are motivated at work.

Motivation can lead a teacher in both positive and negative directions; if it leads the teacher in a positive route, it will result in a positive or good job in accomplishing a certain goal, such as good performance or work performance. However, if a teacher's motivation is negative, he will create bad results or be considered to have failed to achieve a desired aim, namely poor performance and work performance.

Schools, as educational institutions, are constantly striving to improve the educational quality of their students. A positive school climate is required to accomplish this. Working conditions that are immediately perceived by teachers can have an impact on their motivation to do their jobs. Teachers will be more likely to move, raise morale, work discipline, and unleash their powers and skills to reach their goals, which include performance, work performance, and satisfying student learning outcomes, if they perceive a favorable work environment. Meanwhile, if a teacher feels that the work environment is not conducive, he or she will be lethargic, undisciplined, and half-hearted at work, causing the aim to be missed.

Performance is the outcome of specific job functions or activities at specific positions over a period of time. The work outcomes are the product of the employees' abilities, skills, and desires. Mangkunegara (2016) claims that the term performance is derived from the words "work performance" or "real performance" (job performance or actual achievement someone has achieved). The quality and amount of work accomplished by an employee in carrying out his duties under the obligations assigned to him Mangkunegara is defined as performance (2016).

Wibowo (Dekawati, 2020) defines performance as "the execution of a strategy that has been prepared." Human resources with the capacity, competence, motivation, and interests carry out performance implementation. According to Colquitt and Le Pine (Utami, 2019), performance is defined as the value of a set of employee behaviors that contribute to the attainment of corporate goals in both good and negative ways. According to Nawawi (2014), a work target is deemed to be high-performing if it can be accomplished on time or within the time limit set. If it is not performed within the specified time limit or is not completed at all, performance suffers.

Based on some comprehension of the performance given above, it can be determined that performance refers to a person's work accomplishments. The end result of an action carried out to attain a goal is referred to as performance or job performance. The accomplishment of this work is also a manner of evaluating a person's work against a set of criteria.

It is possible to say that someone's performance is accomplishing good performance if their work meets or even surpasses work standards. The expected outcome is for the desired performance to have or generate good quality while still seeing the amount that will be reached. A job must be evaluated in terms of the level of quality obtained as well as the amount of work to be completed as anticipated.

The quality of a teacher's work must meet certain criteria. Teacher performance can be observed and measured against the requirements or competency standards that each teacher must meet. Wagiran (2013) defines teacher performance as the results a teacher achieves in carrying out the tasks entrusted to him, which are based on skills, experience, seriousness, and time, with the resulting output reflected in quantity and quality. The standard of teacher work performance in carrying out their professional duties is stated in Article 20 letter (a) of the In-Law No. 14 of 2005 concerning Teachers and Lecturers, which states that teachers are required to learn plan, carry out a quality learning process, and assess and evaluate learning outcomes. A kind of teacher performance is the instructor's principal task, which is represented in teaching and learning activities.

According to the Ministry of National Education's Directorate General of Human Resource Quality Assurance's Teacher Performance Assessment (PKG) (Dekawati, 2020), performance in the teaching profession is an activity that includes planning learning, implementing learning (KBM), and assessing learning outcomes. Teacher performance, according to Sudarman (2013), may be regarded as the level of 
success of instructors in carrying out educational activities by their responsibilities and authority based on performance standards set for a specific period in the context of accomplishing educational goals.

When a teacher delivers the subject matter in class, the teaching and learning process appears straightforward, but in order to implement successful learning, a teacher must prepare well so that learning may be directed according to the learning objectives contained in the learning success indicators. The learning process is a sequence of activities carried out by a teacher, beginning with learning preparation and progressing to the last stage of learning, which is evaluation and improvement for pupils who were unsuccessful at the time of the evaluation.

Based on the various definitions above, it can be concluded that teacher performance is defined as the success of teachers in carrying out educational tasks in accordance with their responsibilities and authorities based on performance standards set for a specific period, such as planning learning, implementing learning (KBM), and assessing learning outcomes within the framework to achieve educational goals.

Several indicators can be recognized from the function of the instructor in enhancing abilities in the teaching and learning process, according to Usman (2013). The following are the teacher performance indicators: 1) The ability to plan activities for teaching and learning. This competence includes the following: (a) mastering broad lines of education, (b) adjusting subject matter analysis, (c) developing a semester program, (d) developing programs or lessons; 2) ability to carry out teaching and learning activities. These capabilities include: (a) the pre-instructional stage; (b) the instructional stage, and (c) the postinstructional stage; 3) Ability to evaluate Teaching and Learning Activities. 4) Evaluation stage and followup: (a) Normative evaluation is one of these capabilities. (b) Formative assessment, c) A report on the findings of the evaluation, d) Putting improvement and enrichment programs in place.

Teacher performance appraisal can be defined as an attempt to acquire a description of a teacher's knowledge, abilities, values, and attitudes as manifested in their behaviors, appearance, and work performance while performing their tasks and functions (Mulyasa, 2013). Teacher performance appraisal, according to the State Minister for State Apparatus Empowerment and Bureaucratic Reform Regulation No. 16 of 2009, is an assessment of each item of the teacher's major task activities in the framework of nurturing career, rank, and position. Meanwhile, it is said that teacher performance reviews are conducted on a yearly basis, highlighting 14 (fourteen) competence for learning instructors and 17 (seventeen) competencies for counseling teachers/counselors, as well as the completion of other school/madrasah-related activities. Teacher performance appraisal is a system for identifying and evaluating the work performance of teachers, which is mostly related to their competence. Pedagogical competence, personality competence, professional competence, and social competence are the four types of competency. This is done in order to build and develop these skills so that educators can appropriately carry out and carry out their responsibilities (Mulyasa, 2013).

The advantages of performance appraisal, according to Jasmani and Mustofa (2013), include (1) competency modifications; (2) performance improvements; and (3) motivation. (3) Requirements for training and development; (4) Making judgments on where promotions, transfers, dismissals, and workforce planning should be made; (5) For the purpose of staffing research; Based on the above synthesis of theory, teacher performance is defined in research as the result of work or work performance carried out by a teacher based on the ability to manage teaching and learning activities, which includes (1) Learning Planning, (2) Learning Implementation, and (3) Learning Outcomes Assessment Teacher learning performance is linked to their capacity to organize, implement, and assess learning, both in terms of process and outcomes. Mathis and Jackson (Jasmani and Mustofa, 2013) identified three characteristics that influence employee (teacher) performance: ability, effort, and organizational support. Ability (ability/A) x Effort (E) x Support (Support/S) Equals Performance (Performance/P).

If all three components are present, a teacher's performance will improve; however, if one or more of these components is lacking or absent, the teacher's performance will suffer. Meanwhile, Hasibuan (Jasmani and Mustofa, 2013) claims that the following elements influence performance: (1) mental attitudes (work drive, work discipline, and work ethics); (2) education; (3) skills; and (4) management leadership. (5) Economic status; aji and health; (6) Social security; (7) Working environment; (8) Infrastructure; (9) Technology; (10) Possibilities of success. Based on the theoretical definition above, teacher performance can be defined as the execution of teacher activities such as learning planning, implementation, and assessment of student learning outcomes.

Work climate is defined as a psychological environment that can impact organizational members' behavior and is created as a result of organizational actions and interactions. Stringer (Rahsel, 2016) defines 
organizational climate as "anything in the work environment that is perceived directly or indirectly by different persons in that setting." According to Sunyoto (2016), organizational climate is a collection of feelings and views from many workers that might shift over time and from one worker to the next. According to the legislation, the working environment must be pleasant. RI No.9 / 1995 (Tribowono, 2013) is a condition pursued by decision-makers in the form of establishing regulations and policies in every firm activity so that every employee has equal possibilities and as much work support as possible, allowing them to become tough and strong workers. have high levels of performance. The RI Law No. 9/1995 is intended for businesses, but it can be used to assess the working environment in schools. Meanwhile, the work climate is defined by Reichers and Scheinder (Siswanto, 2012) as the perception of policies, practices, and organizational procedures that are sensed and accepted by individuals in the organization, or individual impressions of their workplace. Work atmosphere, according to Haslam et al. (Salindeho, 2016), is described as the perception of policies, practices, and organizational procedures that are felt and accepted by individuals in the organization, or individual impressions of their workplace.

The concept that the work climate is strongly tied to three things: the internal environment of the organization, the persons in the organization, and the unique qualities of one organization to another may be found in several definitions of the work climate (Siswanto, 2012). According to the aforementioned viewpoint, the work climate is a situation that organizations strive for in the form of regulations, policies, opportunities, and support for instructors in their work.

According to Wirawan (Tinambunan, 2019), there are six elements to consider when assessing organizational climate: (1) The framework. The organizational structure accurately reflects the organization's brotherhood and clearly defines duties and responsibilities in the workplace. If the members of the organization believe their work is properly defined, the structure will be high. If they believe there is a lack of clarity regarding who is responsible for the work and who has the ability to make choices, they will choose a low structure. (2) Requirements (Standards). In an organization, standards assess the pressure to improve performance as well as the pride that members of the organization take in their work. Members of a company with high standards are continually seeking for methods to improve performance. Low performance expectations are reflected in low standards. High levels of perceived responsibility suggest that members of the organization are encouraged to solve their concerns. Taking chances and experimenting with new techniques are not appealing when one has a low sense of responsibility. (3) Accountability. Employees' sense of being "boss themselves" and not needing other members of the organization to validate their actions are reflected in the term "responsibility." High levels of perceived responsibility suggest that members of the organization are encouraged to solve their concerns. Taking chances and experimenting with new techniques are not appealing when one has a low sense of responsibility. (4) Acknowledgement If members of the organization can execute a task well, they will receive appreciation. When faced with criticism and task completion penalties, the reward is a measure of reward. A work environment that appreciates performance is marked by a balance of praise and criticism. Low reward suggests that doing a good task is rewarded in an inconsistent manner. (5) Encouragement. Positive leadership and other employees will help to establish a pleasant working environment. Furthermore, support fosters a sense of belonging among employees, allowing them to trust and aid one another, as well as strong working relationships. (6) Dedication (Commitment). Commitment is a measure of how proud members of an organization are of the organization's goals and how dedicated they are to attaining them. An employee's sense of commitment indicates that he or she is invested in the organization's aims.

According to Kusnan (Darodjat, 2015), the following are the organizational climate indicators: (1) Accountability. The way duties are completed and the attainment of employee results inside the firm are characterized as indicators of responsibility. (2) Organizational Individual Identity Individual identity in the workplace refers to employees following Standard Operating Procedures (SOPs) in order to be equally disciplined in their job and achieve company goals. (3) The camaraderie among coworkers. Employee warmth refers to how employees connect with one another in order to build good communication within the firm. (4) Assist. Employees aiding each other and offering support between employees are referred to as support. (5) Dissension. Employees' solutions to difficulties arising from differences of opinion between individuals or groups are classified as conflict. Based on the above theoretical explanation, it can be concluded that the working atmosphere is a condition pursued by organizational leaders in the form of establishing regulations and policies to ensure that teachers have equal chances and support at work.

Motivation is defined as a person's interaction with a circumstance in which there appears to be a difference in the strength of motivation demonstrated by one individual in dealing with a problem compared 
to other persons dealing with the same scenario. The motive is a need, need, desire, or impulse, whereas motivation is the desire to do something (Usman, 2013). Giving the driving force that produces the joy of a person's work so that they are eager to work together, work efficiently, and integrate all of their power and efforts to attain fulfillment is what motivation is defined as (Hasibuan, 2016). Motivation is defined as the readiness to put forth a high level of effort toward organizational goals if such efforts are capable of meeting individual needs (Sedarmayanti, 2014). Work motivation is a psychological process that influences an individual's behavior in the workplace in terms of achieving objectives and tasks. Akyeampon and Bennell (Nyam and William-west, 2014). Motivation is a force that propels people to work (Sutrisno, 2016).

Based on the above discussion of work motivation, it can be concluded that work motivation is an impetus that grows within a person, both inside and outside of himself, to do a job with high enthusiasm, using all of his abilities and skills, and willing to work together to achieve work results that meet his needs.

There are two sorts of job motivation, according to Hasibuan (2017), good motivation and negative motivation, namely: (1) Encouraging motivation (positive incentives). Positive motivation is when a leader encourages (stimulates) subordinates by rewarding those who achieve above expectations. Because humans, on the whole, like to accept what is fine, positive motivation will boost subordinate morale. (2) Unfavorable motive (negative incentives). Negative motivation occurs when a leader drives his followers to the point that they will be punished if they do not meet the standard. The working spirit of subordinates will increase in the short term as a result of this negative incentive since they are terrified of being penalized, but it will have bad implications in the long run.

There are two sorts of motivation, according to Ranupandojo and Husnan (2012), namely: (a) Motivation that is positive. A manager can use positive motivation to motivate staff. This type of positive motivation can take the form of (1) Appreciation for the work done. Most people love being praised for a job well done. As a result, a supervisor should be able to praise or award his employees in order to push them to work more. (2) Knowledge. To avoid misunderstandings and to ensure that a project is completed effectively as required by a company, information on assigned duties must be provided in a clear and concise manner. (3) Paying genuine attention to each employee individually. Every person has a distinct personality, and a manager must pay close attention to these characteristics in order for an employee to understand his or her attention appropriately. (4) There is competition. In general, everyone enjoys competing fairly. Leaders can use this basic mindset to motivate employees to compete fairly for jobs with their coworkers. (5) Involvement. A leader can encourage employee participation by giving them the opportunity to voice their thoughts within the organization. (6) Arrogance. The use of pride as a motivator intersects with the concepts of competition and reward. The thrill and pride that comes with completing a good task is palpable. (7) Cash. This money might be given in the form of a commission or a bonus to employees who finish tasks above and above the standard. (b). Motivation that is negative. Giving negative motivation is a strategy for influencing someone to do something that we want them to do, but it also harms the perpetrator by instilling fear or anxiety in them. Threats and punishments, such as issuing warnings and reducing salaries, can be used to motivate people in a negative way.

Motivation is a psychological process that is influenced by a variety of circumstances. This component can come from both the inside (intrinsic) and the outside (extrinsic) (extrinsic). Internal elements that originate from within the individual and external factors that come from outside the individual are both aspects that influence motivation, according to Wahjosumidjo (2013). Internal variables such as work attitudes, abilities, interests, satisfaction, experience, and so on, as well as external factors such as supervision, remuneration, work environment, and leadership. According to Siagian (2014) motivation is influenced by several factors, both internal and external. Internal factors include: (a) A person's perception of himself. (2) Self-respect. (3) Personal expectations. (4) Needs. (5) Desire. (6) Job satisfaction. (7) The resulting work performance.

Some motivation comes from within the individual, while others come from outside influences. Motivating is a management role that involves this process. Activities during motivation, according to Terry and Rue (Dekawati, 2020), include: (1) coordinating with employees and explaining goals to subordinates. (2) Disseminate implementation metrics and performance benchmarks. (3) Provide training and direction to subordinates in order to ensure that the implementation measures are met. (4) Pay subordinates based on their performance. (5) Be honest in your praise and rebuke. (6) Continue to adjust circumstances and their expectations to create an inspiring environment. (7) Modify and adjust incentive techniques in response to monitoring and changing conditions. (8) Maintain contact throughout the motivational process. 
Based on the overall description of the theories described above, it can be concluded that there are two types of work motivation: positive work motivation and negative work motivation. Positive work motivation occurs when a leader provides motivation or stimulation to subordinates by giving gifts or awards to those who achieve above-average results. Negative motivation occurs when a leader gives motivation or stimulation in the form of punishment to subordinates who lack achievement and excitement for their jobs.

\section{RESEARCH METHODS}

Explanatory research methodologies are used in this study. A research study describes the position of the variables under investigation and the link between one variable and another by putting the hypothesis to the test. The relationship between the independent variable, work climate, and work motivation, and the dependent variable, teacher performance, is examined in this study. This study was carried out in a State Junior High School in Brebes Regency's Losari District.

A proportional random sampling of 155 respondents was obtained from a population of 262 people. Questionnaires, interview techniques, observation, and documentation are all used to collect data. Using the SPSS 23 version, regression and correlation analysis techniques were used to analyze the data.

\section{RESULTS AND DISCUSSION}

If the significance level is less than 0.05 , the $t$ value in the Coefficients table below with the test criteria can be used to determine the extent of the influence of the work climate $\left(\mathrm{X}_{1}\right)$ separately (partially) on teacher performance $(\mathrm{Y})$.

Table 1: Variable Regression Equations for $\mathrm{X}_{1}$ on $\mathrm{Y}$

Coefficients $^{\mathrm{a}}$

\begin{tabular}{|l|r|r|r|r|r|}
\hline \multirow{2}{*}{ Model } & \multicolumn{2}{|c|}{ Unstandardized Coefficients } & $\begin{array}{c}\text { Standardized } \\
\text { Coefficients }\end{array}$ & $\mathrm{t}$ & Sig. \\
\cline { 2 - 6 } & \multicolumn{1}{|c|}{$\mathrm{B}$} & Std. Error & Beta & & \\
\hline \multirow{2}{*}{1 (Constant) } & 70.694 & 5.289 & & 13.366 & .000 \\
\multicolumn{1}{|l}{ Work_Climate_X } & .321 & .083 & .296 & 3.840 & .000 \\
\hline
\end{tabular}

a. Dependent Variable: Teacher_performance_Y

The t-count value of the work climate variable has a p-value of $0.000<0.05$, indicating that it has a significant distribution, according to the t-test results in Table 1. This suggests that the work environment has an impact on teacher performance. The regression equation $\mathrm{y}=\mathrm{a} \mathrm{bx}_{1}$ was calculated using the following results: $\mathrm{Y}=70.694+0.321 \mathrm{X}_{1}$. If the value of the work climate variable improves by 70.694 , the teacher's performance will also increase by 70.694 . A regression coefficient of 0.321 means that for every change in one score or work climate value, a score of 0.321 is generated. The basis for decision-making refers to McCall's (1970) opinion that the significance level should be set at either 5\% or 1\%. According to Azwar (2005), this a priori approach was virtually usually employed in the past, when statistical software was not widely recognized and Statistical Tables were still commonly used. In social studies, we recognize the determination of a significance level of $5 \%$ or $1 \%$ before conducting a statistical test, namely by comparing the $\mathrm{F}$ count with the $\mathrm{F}$ table value as follows: if the significance value is less than 0.05 , Ho is rejected, indicating that the regression coefficient is significant, and otherwise." The significant value was compared with a probability of 0.05 or $5 \%$ in this investigation. That example, if the significance value is less than 0.05 , it indicates that the independent variable has a significant effect on the dependent variable. If the significance value is greater than the probability value of 0.05 , then the independent variable has no effect on the dependent variable Raharjo (2014).

Table 2: Significance of the Effect of Variable $X_{1}$ on $Y$

\begin{tabular}{|l|r|r|r|r|c|}
\hline Model & Sum of Squares & df & Mean Square & F & Sig. \\
\hline Regression & 786.116 & 1 & 786.116 & 14.742 & $.000^{\mathrm{b}}$ \\
1 Residual & 8158.555 & 153 & 53.324 & & \\
Total & 8944.671 & 154 & & & \\
\hline
\end{tabular}


a. Dependent Variable: Teacher_performance_Y

b. Predictors: (Constant), Work_Climate _ $\mathrm{X}_{1}$

The $\mathrm{F}$ value is 14,742 and the significance value is 0.0000 .05 , according to Table 2 of the ANOVA test findings. As a result, Ho is rejected, implying that the impact of the work environment on teacher performance is important. Furthermore, the computation of the coefficient of determination in the table below can be used to determine the degree of the influence of the work atmosphere on teacher performance.

Table 3: Magnitude of the Influence of Variable $X_{1}$ on $Y$

Model Summary

\begin{tabular}{|c|r|r|r|r|}
\hline Model & R & \multicolumn{1}{|c|}{ R Square } & Adjusted R Square & Std. Error of the Estimate \\
\hline 1 & $.296^{\mathrm{a}}$ & .088 & .082 & 7.302 \\
\hline
\end{tabular}

a. Predictors: (Constant), Work_Climate_X

Table 3 shows that $\mathrm{R}$ Square (coefficient of determination) is 0.088 , indicating that the relative constribution of teacher performance is influenced by work climate variables $=\mathrm{R}$ Square $\mathrm{x} 100$ percent or $\mathrm{R}^{2}$ $\mathrm{x} 100$ percent $=0.088 \mathrm{x} 100$ percent $=8.8$. That mean 8.8 percent of teacher performance is influenced by work climate variables, with the remaining 81.2 percent influenced by factors not examined. If the significance level is less than 0.05 , the $t$ value in the Coefficients table below with the test criteria can be used to determine the amount of influence of work motivation $\left(\mathrm{X}_{2}\right)$ separately (partially) on teacher performance (Y).

Table 4: Variable Regression Equations for $\mathrm{X}_{2}$ against $\mathrm{Y}$ Coefficients $^{\mathrm{a}}$

\begin{tabular}{|c|c|c|c|c|c|}
\hline \multirow[t]{2}{*}{ Model } & \multicolumn{2}{|c|}{$\begin{array}{l}\text { Unstandardized } \\
\text { Coefficients }\end{array}$} & Standardized Coefficients & $\mathrm{t}$ & Sig. \\
\hline & B & Std. Error & Beta & & \\
\hline (Constant) & 93.987 & 5.161 & & 18.210 & .000 \\
\hline Work motivation X2 & -.033 & .054 & -.049 & -.607 & .545 \\
\hline
\end{tabular}

a. Dependent Variable: Teacher_performance_Y

The t-count value of the work incentive variable has a p-value of 0.0000 .05 , which suggests it is significant, according to the t-test result table. As a result, work motivation has an impact on teacher performance. The regression equation $\mathrm{Y}=\mathrm{a}+\mathrm{bX} \mathrm{X}_{2}$ was found to be $\mathrm{y}=93,987+0,033 \mathrm{X}_{2}$ based on the calculation results. A constant of 93,987 indicates that if the value of the work incentive variable increases, the teacher's performance will increase by 93,987 .

Every change in one score or work motivation value will result in a score of 0.033 , according to a regression coefficient of 0.033 .

Table 5: Significance of the Effect of Variable $X_{2}$ on $Y$

ANOVA $^{\mathrm{a}}$

\begin{tabular}{|l|r|r|r|r|r|}
\hline Model & Sum of Squares & \multicolumn{1}{|c|}{ df } & Mean Square & F & Sig. \\
\hline Regression & 21.470 & 1 & 21.470 & 2.368 & $.045^{\text {b }}$ \\
1 Residual & 8923.201 & 153 & 58.322 & & \\
Total & 8944.671 & 154 & & & \\
\hline
\end{tabular}

a. Dependent Variable: Teacher_performance_Y

b. Predictors: (Constant), Work motivation $\mathrm{X}_{2}$

The $\mathrm{F}$ value is 2.368 , and the significance is 0.0450 .05 , therefore Ho is rejected, indicating that the effect of work motivation on performance is substantial, according to the ANOVA test findings in Table 5. Furthermore, the computation of the coefficient of determination in the table below can be used to determine the degree of the influence of work motivation on teacher performance (Table 6). 
Table 6: Magnitude of the Influence of Variable $\mathrm{X}_{2}$ on $\mathrm{Y}$ Model Summary

\begin{tabular}{|c|r|r|r|r|}
\hline Model & \multicolumn{1}{|c|}{ R } & \multicolumn{1}{|c|}{ R Square } & Adjusted R Square & Std. Error of the Estimate \\
\hline 1 & $.049^{\mathrm{a}}$ & .002 & -.004 & 7.637 \\
\hline
\end{tabular}

a. Predictors: (Constant), Work motivation $\mathrm{X}_{2}$

Table 6 shows that $\mathrm{R}$ Square is 0.002 , indicating that the relative constribution of teacher performance is driven by work incentive variables $=\mathrm{R}$ Square $\mathrm{x} 100$ percent or $\mathrm{R}^{2}$ x 100 percent $=0.002 \mathrm{x}$ 100 percent $=0.2$ percent. The other $99.8 \%$ influenced by factors not researched.

If the significance level is less than 0.05 , the $t$ value in the Coefficients table below with the test criteria can be used to determine the degree of the influence of work atmosphere and work motivation combined (simultaneously) on teacher performance.

Table 7: Regression Equations. $X_{1}$ and $X_{2}$ against $Y$

Coefficients $^{\mathrm{a}}$

\begin{tabular}{|c|c|c|c|c|c|}
\hline \multirow[t]{2}{*}{ Model } & \multicolumn{2}{|c|}{$\begin{array}{c}\text { Unstandardized } \\
\text { Coefficients }\end{array}$} & Standardized Coefficients & $\mathrm{t}$ & Sig. \\
\hline & B & Std. Error & Beta & & \\
\hline (Constant) & 78.737 & 5.369 & & 14.666 & .000 \\
\hline 1 Work_Climate_X1 & .598 & .103 & .553 & 5.812 & .000 \\
\hline Work_motivation_X2 & .268 & .063 & -.402 & -4.226 & .000 \\
\hline
\end{tabular}

a. Dependent Variable: Teachers Performance_Y

The t-count value of the work climate variable and work motivation together (simultaneously) has a p-value of 0.0000 .05 , which suggests it is significant, according to the t-test results in Table 7 . Thus, both the work atmosphere $\left(\mathrm{X}_{1}\right)$ and work motivation $\left(\mathrm{X}_{2}\right)$ affect teacher performance (simultaneously) (Y). The regression equation can be found by looking at the table above. The multiple linear regression equation is shown in the table: $=78,737+0.598 \mathrm{X}_{1}+0.268 \mathrm{X}_{2}$. According to this equation, adding and-of 1 increases $\mathrm{Y}$ by 0.598 and 0.268 , implying that increasing work atmosphere and motivation by 1 increases teacher performance by 0.598 and 0.268 .

According to the $\mathrm{F}$ value of 17.112 and the significance of 0.0000 .05 in the ANOVA test table 8 below, Ho is rejected, indicating that the combined influence of work atmosphere and work motivation on performance is substantial. Furthermore, the computation of the coefficient of determination in the table below can be used to assess the magnitude of the influence of work atmosphere and work motivation combined (simultaneously) on teacher performance (Table 8).

Table 8: Significance of the Effect of Var. $X_{1}$ and $X_{2}$ against $Y$ ANOVA $^{\mathrm{a}}$

\begin{tabular}{|l|r|r|r|r|r|}
\hline Model & Sum of Squares & df & Mean Square & F & Sig. \\
\hline Regression & 1643.842 & 2 & 821.921 & 17.112 & $.000^{\mathrm{b}}$ \\
1 Residual & 7300.829 & 152 & 48.032 & & \\
Total & 8944.671 & 154 & & & \\
\hline
\end{tabular}

a. Dependent Variable: Teachers Performance_Y

b. Predictors: (Constant), Work motivation_X $\mathrm{X}_{2}$, Work Climate_ $\mathrm{X}_{1}$

Table 9: Magnitude of Var's Influence. $X_{1}$ and $X_{2}$ against Var. $Y$ Model Summary

\begin{tabular}{|l|r|r|r|r|}
\hline Model & R & R Square & Adjusted R Square & Std. Error of the Estimate \\
\hline 1 & $.429^{\mathrm{a}}$ & .184 & .173 & 6.930 \\
\hline
\end{tabular}

a. Predictors: (Constant), Work motivation $\mathrm{X}_{2}$, Work_Climate $\mathrm{X}_{1}$ 
The coefficient of determination $(\mathrm{R}$ Square $)=0.184$. That mean relative constribution of teacher performance is influenced by work climate variables and work motivation together (simultaneously) $=R^{2} \mathrm{x}$ 100 percent $=0.184 \times 100$ percent $=18.4$ percent, while the remaining 81.6 percent is influenced by other factors not examined. The research question is whether or not the work environment influences teacher performance. The study's findings suggest that: (1) the work climate has a considerable impact on teacher performance, and (2) the scale of the contribution of the work climate to teacher performance is suggested by the study's findings that the work climate consists of the following dimensions: (UU. RI No.9/1995 Tribowono, 2013) has significant implications for teacher performance, which includes the following dimensions: (a) establishing regulations; (b) determining policies; (c) getting the same opportunity; (d) support at work, (UU. RI No.9/1995 - Tribowono, 2013) has significant implications for teacher performance, which includes the following dimensions: (1) lesson planning; (2) learning implementation; (3) evaluation of learning outcomes. (Dekawati, 2020, National Educational Ministry, Directorate General of Human Resource Quality Assurance). However, the teacher's work performance is influenced by more than just the work environment; there are other elements (epsilon) that contribute as well, which are not explored in this study. Findings The findings of this study agree with those of Arikunto et al. (2015), who found that a positive school climate, which can take the shape of a physical or non-physical work environment, can affect teacher performance at a school. Meanwhile, Batlolona (2018) discovered that school climate and culture are entertaining and constantly supports a teacher so that they work enthusiastically to improve their work, which is obtained from a synergistic collaborative collaboration between schools, government, and educational communities. The Principal is responsible for efficiently and successfully managing all school resources in order to improve the school and provide a work environment that encourages teachers to continue to initiate, artistically, and innovatively produce learning materials presented in the classroom.

This study agrees with Hamsah et al. (2019), who found that the work environment has a beneficial impact on teacher performance. The findings of De Roche's research (in Malang, 2012) confirm that the work climate may be split into two categories: negative and positive. In schools, there is a bad work climate characterized by a lack of direction, communication, creativity and innovation, student exclusion, and so on. Whereas in a positive work climate, school members are aware of the causes of a conflict and take steps to resolve it, conflict and criticism are seen as opportunities to recognize strengths and weaknesses, the principal values each student's ideas, suggestions, and participation, there is trust and openness, productivity, cooperation, and involvement of high school citizens, and so on. As a result, the findings of this study suggest that the better the working environment, the better the teacher's work performance.

The regression equation $\mathrm{Y}=70.694+0.321 \mathrm{X}_{1}$ can explain this. If the work climate and teacher performance are measured by the instrument produced in this study, then every change in the work climate score of one unit may be estimated to change the teacher performance score 0.296 units in the same direction, according to this regression equation.

The findings of this study provide some information based on empirical findings that indicate a significant influence of work climate on teacher performance, including (1) Work climate conditions influence teacher performance, (2) Increasing work climate is one way to improve teacher performance, and (3) The magnitude of the influence of work climate on teacher performance is $8.8 \%$, while the rest is influenced by other variables, apart from work climate (epsilon). The research question is whether or not work motivation influences teacher performance. Empirically, the findings of this study show that: (1) work motivation has a significant effect on teacher performance, and (2) the magnitude of work motivation's contribution to teacher performance is indicated by the study's findings, which show that high work motivation consists of the following dimensions: (1) positive motivation; (2) negative motivation (Hasibuan, 2017), both of which have substantial implications for teacher performance in the aspects listed below: (1) Learning planning; (2) Learning implementation; (3) Learning outcome assessment. (Dekawati, 2020, National Educational Ministry, Directorate General of Human Resource Quality Assurance). As a result of the findings of this study, more (excellent) teacher work motivation leads to higher teacher performance. The regression equation $\mathrm{Y}=93,987+0.033 \mathrm{X}_{2}$ can explain this. If the work motivation and teacher performance are measured by the instrument produced in this study, then each change in the work motivation score of one unit can be estimated to change the teacher performance score 0.033 units in the same direction, according to the regression equation.

This contradicts the findings of Ardiana's (2017) study, which found that work motivation has a favorable impact on teacher performance, and Rahmi and Zulminiati's (2019) study, which found that work motivation has a positive link with teacher performance. The teacher's performance will be high if he or she 
is motivated at work. Motivation can lead a teacher in both positive and negative directions; if it leads the teacher in a positive route, it will result in a positive or good job in accomplishing a certain goal, such as good performance and work performance. If, on the other hand, motivation leads the teacher in a negative way, he will create poor outcomes or, in other words, he would fail to achieve a desired aim, namely poor performance and work performance. The outcomes of this study present some information based on empirical data that demonstrate a major influence of work motivation to teacher performance, including: (1) Teacher work motivation influences teacher performance, (2) Increasing/improving teacher work motivation is one way to improve teacher performance, and (3) Work motivation has a 0.2 percent influence on teacher performance, with the rest influenced by other variables (aside from work climate variables, which are not studied in this study) (epsilon). The research question is whether the work environment and motivation effect teacher performance at the same time. The findings of this study show that: (1) there is a significant influence of work climate and work motivation on teacher performance at the same time, and (2) the magnitude of the influence of work climate and work motivation on teacher performance is indicated by the study's findings that the working climate consists of the following dimensions: (UU. RI No.9 / 1995 Tribowono, 2013), as well as teacher work motivation, which includes dimensions: (1) Determination of regulations; (2) Determination of policies; (3) Get the same opportunity; (4) support at work, (UU. RI No.9 / 1995 - Tribowono, 2013), as well as teacher work motivation, which includes dimensions: (1) Determination of regulations; (2) Determination of policies; (3) Get the same opportunity; (4) support (1) motivation that is positive; (2) motivation that is negative (Hasibuan, 2017) has important consequences for teacher performance in terms of the following dimensions: (1) learning planning; (2) learning implementation; (3) evaluation of learning outcomes (National Educational Ministry - Directorate General of Human Resource Quality Assurance-Dekawati, 2020).

In contrast to Hartoyo's (2017) findings, which show that work motivation has a significant positive effect on teacher performance, work climate has no effect on teacher performance, the principal's work climate has a significant positive effect on teacher performance, and the head's work climate helps to strengthen the effect of work motivation on teacher performance. The principal's work climate has little bearing on the impact of the work climate on teacher performance in schools. Research Sinaulan (2016) investigated how school climate variables, work stress, and work motivation affect teacher performance. The findings of this study show that (1) school atmosphere has an impact on teacher performance. (2) Teacher performance is influenced by job stress. (3) Teacher performance is influenced by job motivation. (4) The school climate has an impact on teacher work motivation. (5) Job stress has an impact on teacher work motivation. This suggests that increasing workplace stress among teachers may have an impact on their motivation to work. Low stress, on the other hand, can boost teacher motivation at work. However, teacher performance is influenced not only by the work environment and motivation, but also by other factors (epsilon) that are not studied in this study. As a consequence of the findings of this study, it appears that the better the working environment and work motivation of teachers are, the greater the teacher performance will be. The regression equation $=78.737+0.598 \mathrm{X}_{1}+0.268 \mathrm{X}_{2}$ can explain this. If the work climate, work motivation, and instructor performance are measured by the instrument developed in this study, then each change in the work climate score and work motivation is simultaneously equal to one unit, according to this regression equation. The teacher performance score is expected to alter 0.598 and 0.268 units in the same direction. The findings of this study provide some information based on empirical findings that indicate a significant influence of work climate and work motivation on teacher performance, including: (1) The implementation of work climate and work motivation has an influence on teacher performance, (2) Improving the work climate and improving work motivation is one way to improve teacher performance. (3) Working climate and work motivation have a combined effect of 18.4 percent on teacher performance, with the rest influenced by other variables not examined in this study (epsilon).

\section{CONCLUSIONS}

After reviewing the findings of this study, it can be concluded that: (1) Workplace climate has a favorable and significant impact on teacher performance. (2) Work motivation has a favorable impact on teacher performance. (3) Workplace atmosphere and motivation have a positive and considerable impact on teacher performance at the same time. Based on these circumstances, the authors propose that: (1) Work atmosphere and motivation have an impact on teacher performance, according to research findings. Meanwhile, teacher performance, particularly in terms of planning and implementing learning, remains a 
source of worry. As a result, the principle should assist teachers on how to create a proper learning implementation plan and conduct supervision so that learning is better implemented. (2) To improve teacher performance through improving the work environment, clear regulations and more support for a smooth learning process should be prioritized. Meanwhile, in order to improve teacher performance through work motivation, an emphasis on negative motivation should be implemented, with appropriate rewards and punishments.

\section{REFERENCES}

Ardiana, T.E. (2017). Pengaruh Motivasi Kerja Guru Terhadap Kinerja Guru Akuntansi SMK Di Kota Madiun. Jurnal Akuntansi Dan Pajak, Vol. 17, No. 02, Januari, 14-23.

Arikunto, S. (2015). Dasar-Dasar Evaluasi Pendidikan. Jakarta: Bumi Aksara.

Batlolona, J.F. (2018). Organizational Climate of the School and Teacher Performance Improvement in the 21st Century. International Journal of Science and Research (IJSR) • Volume 7 Issue 2, February, 119126.

Darodjat, T.A. (2015). Konsep-Konsep Dasar Manajemen Personalia-Masa Kini. Bandung: PT Refika Aditama.

Dekawati, Ipong. (2020). Manajemen Pengembangan Guru Profesional (Suatu Tinjauan Teoritik dan Empirik ). Bandung: Rizqi Press.

Hamsah, dkk. (2019). Pengaruh Iklim Kerja Terhadap Kinerja Guru Pada Madrasah Aliyah di Kecamatan Gantarang Kabupaten Bulukumba. Jurnal Idaarah, Vol. III No. 2, Desember, 237-244.

Hartoyo, S.E. (2017). Pengaruh Motivasi Kerja Dan Iklim Kerja Terhadap Kinerja Guru Dengan Moderasi Kepemimpinan Transformasional Kepala Sekolah Studi Pada Sekolah Di Yayasan Institut Indonesia 48 Cabang Semarang. Jurnal Telaah Manajemen Vol. 14 Edisi 1, 43 -56.

Hasibuan, M.S.P. (2017). Manajemen Sumber Daya Manusia. Edisi Revisi. Jakarta: Bumi Aksara.

Jasmani dan Mustofa, S. (2013). Supervisi Pendidikan Terobosan Baru dalam Peningkatan Kinerja Pengawas Sekolah dan Guru. Yogyakarta: AR-RUZZ Media.

Mangkunegara, A. A. P. (2016). Manajemen Sumber Daya Manusia Perusahaan. Bandung: PT. Remaja Rosdakarya.

McCall, R.B. (1970). Fundamental Statistics for Psychology. New York: Harcourt, Brace \& World, Inc.

Mulyasa, E. (2007). Standar Kompetensi dan Sertifikasi Guru. Bandung: PT. Remaja Rosdakarya.

Mulyasa, E. (2013). Pengembangan dan Implementasi Kurikulum 2013. Bandung: PT Remaja Rosdakarya.

Nawawi, Hadari. (2014). Manajemen Sumber Daya Manusia Untuk Bisnis Yang Kompetitif. Yogyakarta: Gajah Mada University Press.

Nyam, J. \& William-west, O. (2014). Teachers Motivation: A Study of The Psychological and Social Factors. International Journal of Education and Research. Vol. 2 No. 2, February, 1-8.

Raharjo, Sahid .(2014). Uji Regresi Sederhana dengan SPSS Lengkap (https://www.konsistensi.com/2014/06/uji-regresi-sederhana-dengan-spss.html)

Rahmi, F dan Zulminiati. (2019). Hubungan Motivasi Kerja Dengan Kinerja Guru Taman Kanak Kanak di Kecamatan Padang Utara Kota Padang. Jurnal Bahana Manajemen Pendidikan Volume 8 Nomor 2, Mei, 37-46.

Rahsel, Y. (2016). Pengaruh Iklim Kerja Terhadap Kinerja Pegawai Administrasi Pusat Universitas Padjadjaran Bandung (Studi Pada Bagian Administrasi Umum UNPAD). Jurnal Manajemen Magister, Vol 02. No.01, Januari, 105-117.

Ranupandojo, H dan Husnan, S. (2012). Manajemen Personalia.Yogyakarta: BPFE-Yogyakarta.

Salindeho, C.L. (2016). Analisis Pengaruh Iklim Kerja dan Pengembangan Karir Terhadap Komitmen Karir Dengan Kepuasan Kerja Sebagai Variabel Intervening. Jurnal Riset Bisnis dan Manajemen Vol 4 No.3, 303-318.

Sedarmayanti. 2014. Sumber Daya Manusia Dan Produktivitas Kerja. Bandung: Mandar Maju

Siagian, S.P. (2014). Manajemen Sumber Daya Manusia. Jakarta: Bumi Aksara.

Sinaulan, R.L. (2016). Effect of School Climate, Work Stress and Work Motivation on Performance of Teacher. GUIDENA Jurnal Ilmu Pendidikan, Psikologi, Bimbingan dan Konseling, Vol. 6 No. 2, 146153. 
Siswanto. (2012). Pengantar Manajemen. Jakarta: Bumi Aksara.

Sudarman, D. (2013). Media Komunikasi Pendidikan Pelayanan Profesional Pembelajaran dan Mutu Hasil Belajar. Jakarta: PT. Bumi Aksara.

Surya, M. (2004). Psikologi Pembelajaran dan Pengajaran. Bandung: Pustaka Bani Quraisy.

Sutrisno, E. (2016). Manajemen Sumber Daya Manusia. Jakarta: Kencana Prenada Media Group.

Syarifudin, A. (2019). Peningkatan Kinerja Guru Dalam Pembelajaran di Kelas Melalui Supervisi Edukatif Kolaboratif Secara Periodik". Jurnal Mitra Pendidikan Volume VI, Nomor 1, Januari, 14-25.

Tinambunan, A.K. (2019). Analisis Iklim Organisasi PT. Sharon. Prosiding No. 2. Festival Riset Ilmiah Manajemen dan Akuntansi.

Tribowono. (2013). Manajemen Iklim Kerja. Jakarta: Rajawali Pers.

Usman, H. (2013). Manajemen Teori, Praktik, dan Riset Pendidikan. Edisi Keempat. Jakarta Timur: Bumi Aksara.

Utami, N.M.S. (2019). Determinants of Teacher Performance And Education Power Through Work Motivation, Learning Leadership, And Organizational Culture (A Study At Public Elementary School In West District Of Denpasar). IJSEGCE VOL 2, No.2, July, 13-20.

Wagiran. (2013). Kinerja Guru. Yogyakarta. Deeppublish.

Wahjosumidjo. (2013). Kepemimpinan Kepala Sekolah: Tinjauan Teoritik dan Permasalahannya. Jakarta: PT. Raja Grafindo Persada.

Malang, Y. Y. (2012). Hubungan Iklim Sekolah, Beban Tugas, Motivasi Berprestasi, dan Kepuasan Kerja Guru dengan Kinerja Guru SD. Jurnal Manajemen Pendidikan Universitas PGRI Semarang, 1(3), 112361. 